\title{
Sediment discharge variability in Arctic rivers: implications for a warmer future
}

\author{
James P. M. Syvitski
}

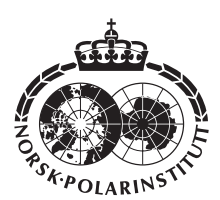

A new model for predicting the sediment flux in ungauged river basins is applied to 46 Arctic to sub-Arctic rivers. The model predicts the preanthropogenic flux of sediment to within a factor of 2, across four orders of magnitude in basin area and run-off. The model explains for the first time why Arctic rivers carry so little sediment when compared at the global scale. Sensitive to drainage basin temperature, the model is used to examine the impact of a climate warming scenario on the loads of high latitude rivers. As the Arctic warms, rivers will carry increased sediment loads, similar to more temperate rivers. For every $2{ }^{\circ} \mathrm{C}$ warming, the model predicts a $22 \%$ increase in the flux of sediment carried by rivers. For every $20 \%$ increase in water discharge there will be a $10 \%$ increase in sediment load. The model also aids the interpretation of palaeoclimate records obtained from Arctic continental margins.

J. P. M. Syvitski, Institute of Arctic and Alpine Research, University of Colorado, 1560 30th St., Boulder, CO 80309-0450, USA.

Compared to temperate and tropical rivers, the sediment load discharged by Arctic rivers is relatively low (Fig. 1a) in spite of large unconsolidated sedimentary deposits located throughout the Arctic, particularly in regions where the imprint of Pleistocene ice sheets remains evident. This puzzle is at a time when Arctic coastal erosion appears to be accelerating (Peckham et al. 2001). Siberian rivers are known to transport very low sediment loads (Lopatin 1952; Alekseev \& Lisitsyna 1974), while Canadian rivers like the Mackenzie are considered normal (Milliman \& Meade 1983). Bobrovitskaya et al. (1996) suggested that the expanses of swamp and forest in the hinterlands of Siberian rivers could account for their low load. Gordeev (2000) suggested that differences between Russian and Canadian rivers are more a function of plate tectonics and the nature of the regional bedrock. Recently Morehead et al. (in press) developed a fluvial model that suggested long-term sediment loads are partly dependent on the temperature of a drainage basin: if the temperature is low, so is the relative load that a river can transport.
A new (2001) multi-agency SEARCH report (http://psc.apl.washington.edu/search/) warns: "it is alarmingly clear that a complex suite of significant, interrelated atmospheric, oceanic and terrestrial changes has occurred in the Arctic in recent decades." These changes may provide a large-scale manifestation of greenhouse warming:

1) rapid penetration of the warmer Atlantic water into the Arctic Ocean, concomitant with changes in surface water circulation and ice drift, and therefore changes in atmospheric pressure patterns (Steele \& Boyd 1998; Maslanik et al. 1999);

2) warming of surface air temperature and increase in cloudiness (Serreze et al. 2000);

3) decrease in coastal ice extent thereby increasing in storm fetch and surge, and mechanicalthermal erosion of the coastal zone (e.g. Forbes \& Syvitski 1995); and

4) reduction in snow cover and increase in ablation of glacier ice inducing changes in Arctic hydrology (Lemeshko 1992; Petersen et al. 1995; Van Blarcum et al. 1995; Dyurgerov \& Meier 1997; Kovalevsky 1998; Lammers et al. 2001).

The Arctic Ocean receives enough freshwater 

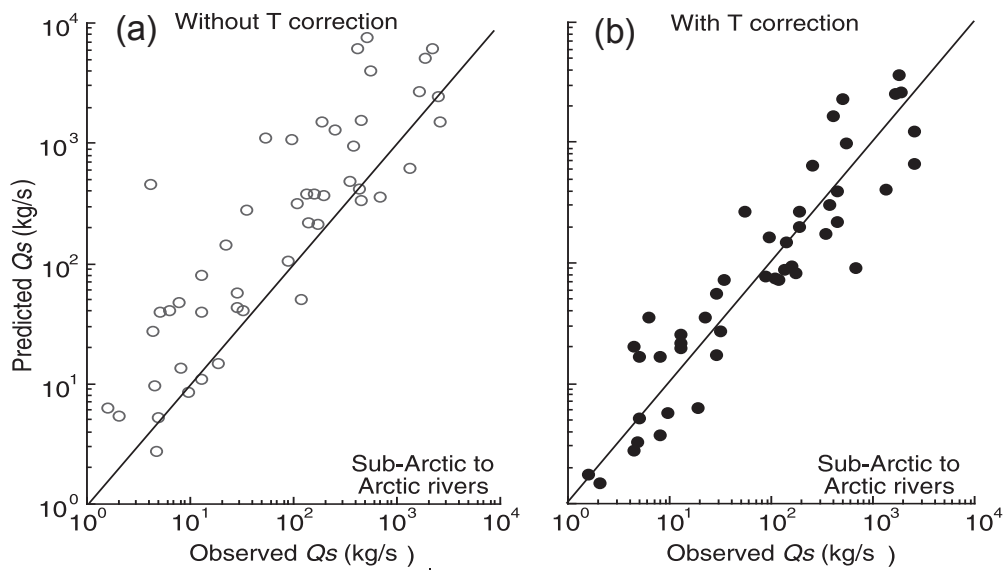

Fig. 1. (a) Sediment load (Qs) for sub-Arctic and Arctic rivers, predicted without a temperature correction but based on a global expression $\left(Q_{S}=\beta H^{3 / 2} A^{1 / 2}\right.$ see Syvitski \& Morehead 1999) of the measured sediment load (Milliman \& Syvitski 1992). Many rivers are predicted to transport more sediment than observed. (b) Rivers corrected for their cold basin temperatures (i.e. $Q s=\alpha H^{3 / 2} A^{1 / 2} \mathrm{e}^{k T}$ ) fall on the global regression.

discharge to determine its properties and circulation (Carmack 2000). Four of the world's largest 15 rivers drain into the Arctic Ocean (Ob, Yenisei, Lena, Mackenzie); two others (Amur, Yukon) drain into the North Pacific. Draining significant tracts of permafrost terrain, their hydrology is dominated by the melt of seasonal snowfall. Extreme events often control the land-sea flux of material in the circum-Arctic (Lisitsyna 1974). Large Arctic rivers can discharge $90 \%$ of their sediment load in a month or less (Bobrovitskaya et al. 1996, 1997). Other comparably sized temperate or tropical rivers lack this type of dynamic response (Wang et al. 1998).

A warming of between $4{ }^{\circ} \mathrm{C}$ and $6^{\circ} \mathrm{C}$ is predicted for the central Arctic by the middle of the 21st century $\left(\times 2 \mathrm{CO}_{2}\right.$ scenario; Manabe et al. 1991; Lewis et al. 2001). Sediment flux by high latitude rivers is expected to increase (Syvitski \& Andrews 1994). Unfortunately at this critical time of change, there has been a rapid decrease in the monitoring of pan-Arctic rivers, both for their water discharge (Shiklomanov et al. 2002) and for their sediment load (Syvitski et al. 2000). This paper examines the flux of sediment from Arctic and sub-Arctic rivers, and applies a model for estimating the sediment flux for ungauged rivers given a climate warming scenario.

\section{Drainage basin properties affecting sediment load}

A variety of non-anthropogenic factors influence the "natural" sediment load of a river, but the significant factors are the size of a drainage basin
(Wilson 1973; Milliman \& Syvitski 1992) and large-scale relief within it (Pinet \& Souriau 1988; Milliman \& Syvitski 1992; Harrison 1994). Other influences scale with one of these two parameters. For example, local relief (Ahnert 1970; Jansen \& Painter 1974) is correlative with large-scale relief (Summerfield \& Hulton 1994), and ice cover and ice-melt scales with solar radiation and relief (Andrews \& Syvitski 1994). Precipitation intensity is captured in part through basin relief (Fournier 1960; Jansen \& Painter 1974; Hay et al. 1987). Run-off is correlative with basin area (Walling 1987; Milliman \& Syvitski 1992; Mulder \& Syvitski 1996): in our Arctic river data (Table 1), average discharge $Q$, scales with basin area $A\left(Q=0.93 A^{0.82}\right.$ at $\mathrm{R}^{2}=0.892$; Fig. 2).

Vegetation scales with both regional temperature and precipitation and can influence on a river's sediment load (Douglas 1967). The rock and soil type within a basin also provides local variability to sediment delivery (Pinet \& Souriau 1988; Milliman \& Syvitski 1992; Inman \& Jenkins 1999). Lakes may filter out a river's sediment load (Vörösmarty et al. 2001); Arctic terrain has a high density of lakes (Milliman 1980). Basin temperature influences the sediment load carried by rivers through control of the number of soil-forming frost cycles and (frozen) ground conditions (Syvitski \& Morehead 1999).

\section{High latitude drainage basin data}

Table 1 provides data on the drainage properties of 46 Arctic and sub-Arctic rivers that represent the spectrum of northern environments. The data 
set includes 28 rivers that together account for $70 \%$ of the land surface draining into the Arctic Ocean (Prowse \& Flegg 2000), 13 rivers that drain into the North Atlantic (including Hudson Bay), and 7 rivers that drain into the North Pacific through coastal mountain ranges. The rivers are located in Russia, Canada or the US, with one Finnish river to represent coastal plain subArctic drainage. Drainage area $A$ varies across five orders of magnitude, from $90 \mathrm{~km}^{2}$ (South) to $2929000 \mathrm{~km}^{2}(\mathrm{Ob})$. Relief $H$, is measured between the elevation of the gauging station and the highest point of land, and varies from $75 \mathrm{~m}$ (Kalkkinen, Finland) to $6094 \mathrm{~m}$ (Yukon, Alaska). Long-term sediment discharge varies from $0.1 \mathrm{~kg} / \mathrm{s}$ (Kalkkinen) to $2580 \mathrm{~kg} / \mathrm{s}$ (Liard). Some rivers have very low turbidity levels (e.g. $0.01 \mathrm{~kg} / \mathrm{m}^{3}$ : Attawapiskat), while others are

Table 1. Drainage properties of 46 Arctic and sub-Arctic rivers derived from the databases of Binda et al (1986), Milliman \& Syvitski (1992, with revisions from Bobrovitskaya et al. 1996, 1997), Gordeev (2000) and Syvitski et al. (2000).

\begin{tabular}{|c|c|c|c|c|c|c|c|c|c|c|c|c|c|}
\hline River & $\begin{array}{c}\text { Receiving } \\
\text { ocean }\end{array}$ & $\begin{array}{l}\text { Area } \\
\left(\mathrm{km}^{2}\right)\end{array}$ & $\begin{array}{l}H^{\mathrm{b}} \\
(\mathrm{m})\end{array}$ & $\begin{array}{c}\text { Mean } T^{\circ} \\
\left({ }^{\circ} \mathrm{C}\right)\end{array}$ & $\begin{array}{c}\mathrm{Q}^{\mathrm{d}} \\
\left(\mathrm{m}^{3} / \mathrm{s}\right)\end{array}$ & $\begin{array}{c}C s^{\mathrm{e}} \\
\left(\mathrm{kg} / \mathrm{m}^{3}\right)\end{array}$ & $\begin{array}{c}Q s^{\mathrm{f}} \\
(\mathrm{kg} / \mathrm{s})\end{array}$ & $\begin{array}{l}\text { Pred. } Q s^{\mathrm{g}} \\
\quad(\mathrm{kg} / \mathrm{s})\end{array}$ & $\begin{array}{c}T-P Q s^{\mathrm{h}} \\
(\mathrm{kg} / \mathrm{s})\end{array}$ & $\begin{array}{c}Q-P Q s^{\mathrm{i}} \\
(\mathrm{kg} / \mathrm{s})\end{array}$ & $\begin{array}{l}\text { Pred. } \\
C^{\mathrm{j}}(-)\end{array}$ & $\begin{array}{l}\text { Obs. } \\
C^{\mathrm{k}}(-)\end{array}$ & $\begin{array}{c}P \sigma-c \\
(-)\end{array}$ \\
\hline South (Can) & Atl. & 90 & 1025 & -13 & 1 & 1.350 & 2 & 6 & 2 & 1 & 1.87 & & 0.17 \\
\hline Middle (Can) & Atl. & 110 & 865 & -13 & 2 & 1.100 & 2 & 5 & 1 & 1 & 1.82 & & 0.17 \\
\hline North (Can) & Atl. & 190 & 1060 & -13 & 4 & 1.160 & 4 & 10 & 3 & 2 & 1.93 & & 0.17 \\
\hline Ekalugad Fjord (Can) & n) Atl. & 380 & 1060 & -13 & 7 & 1.180 & 8 & 13 & 4 & 3 & 1.98 & & 0.17 \\
\hline St. Jean (Can) & Atl. & 5600 & 990 & 1 & 1100 & 0.010 & 8 & 47 & 16 & 75 & 2.13 & & 0.19 \\
\hline Murray (Can) & Arct. & 5620 & 1686 & -3 & 452 & 0.192 & 87 & 104 & 77 & 174 & 2.31 & 2.70 & 0.18 \\
\hline Homathko (Can) & Pac. & 5700 & 3994 & 2 & 253 & 0.540 & 136 & 381 & 89 & 527 & 2.79 & 2.60 & 0.17 \\
\hline Odei R (Can) & Atl. & 6130 & 222 & 0 & 67 & 0.075 & 5 & 5 & 5 & 4 & 1.67 & 1.60 & 0.17 \\
\hline Klinaklini (Can) & Pac. & 6500 & 3800 & 2 & 330 & 0.480 & 158 & 378 & 92 & 566 & 2.77 & & 0.18 \\
\hline N Saskatchewan (Car & an) Atl. & 11000 & 2212 & -4 & 156 & 0.891 & 139 & 218 & 146 & 128 & 2.49 & 2.40 & 0.17 \\
\hline Romaine (Can) & Atl. & 14000 & 650 & 0 & & & 5 & 39 & 17 & & 2.03 & & \\
\hline Arctic Red (Can) & Arct. & 18600 & 2452 & -4 & 752 & 0.192 & 452 & 331 & 222 & 237 & 2.60 & 2.80 & 0.18 \\
\hline Stikine (Can) & Pac. & 18800 & 1808 & 4 & 578 & 0.296 & 171 & 211 & 82 & 253 & 2.42 & 2.60 & 0.18 \\
\hline Muskwa (Can) & Arct. & 20300 & 2522 & 0 & 452 & 1.520 & 687 & 361 & 92 & 364 & 2.59 & 2.40 & 0.18 \\
\hline Abitibi (Can) & Atl. & 24000 & 430 & -3 & 1680 & 0.003 & 4 & 28 & 20 & 46 & 1.95 & & 0.20 \\
\hline Kymijoki (Fin) & Atl. & 37240 & 80 & 3 & 288 & 0.020 & 5 & 3 & 3 & 2 & 1.56 & & 0.18 \\
\hline Skeena (Can) & Pac. & 42000 & 2409 & 4 & 918 & 0.380 & 349 & 485 & 174 & 574 & 2.62 & 2.70 & 0.19 \\
\hline Colville (US) & Arct. & 50000 & 4800 & -17 & 492 & 0.390 & 190 & 1487 & 269 & & 3.14 & & 0.18 \\
\hline Attawapiskat (Can) & Atl. & 50200 & 430 & -1 & 626 & 0.010 & 6 & 40 & 35 & 21 & 2.02 & & 0.18 \\
\hline Onega (Rus) & Arct. & 57000 & 147 & -4 & 500 & 0.018 & 10 & 9 & 6 & 4 & 1.75 & & 0.18 \\
\hline Moose (Can) & Atl. & 60000 & 400 & 0 & 780 & 0.020 & 13 & 39 & 22 & 27 & 2.00 & & 0.18 \\
\hline Nadym (Rus) & Arct. & 64000 & 550 & -9 & 570 & 0.022 & 13 & 11 & 26 & 2 & 1.83 & & 0.18 \\
\hline Nottaway (Can) & Atl. & 65800 & 400 & 3 & 1130 & 0.030 & 32 & 41 & 27 & 38 & 2.00 & & 0.19 \\
\hline Alazeya (Rus) & Arct. & 68000 & 914 & -14 & 280 & 0.080 & 22 & 144 & 36 & 12 & 2.32 & & 0.18 \\
\hline Peel (Can) & Arct. & 70600 & 2362 & -4 & 1492 & 0.896 & 1337 & 610 & 409 & 327 & 2.68 & 2.60 & 0.20 \\
\hline Mezen (Rus) & Arct. & 78000 & 900 & -10 & 860 & 0.032 & 29 & 57 & 56 & 21 & 2.09 & & 0.19 \\
\hline Kuskokwim (US) & Pac. & 80500 & 3700 & -7 & 1293 & 0.200 & 254 & 1277 & 634 & 398 & 2.98 & & 0.19 \\
\hline Anabar (Rus) & Arct. & 100000 & 536 & -14 & 550 & 0.024 & 13 & 78 & 19 & 8 & 2.18 & & 0.18 \\
\hline Pyr (Rus) & Arct. & 112000 & 168 & -9 & 1080 & 0.018 & 19 & 15 & 6 & 3 & 1.87 & & 0.19 \\
\hline Taz (Rus) & Arct. & 150000 & 312 & -9 & 1400 & 0.021 & 29 & 43 & 17 & 10 & 2.09 & & 0.20 \\
\hline Pyasina (Rus) & Arct. & 182000 & 1100 & -14 & 2730 & 0.040 & 108 & 311 & 75 & 65 & 2.45 & & 0.22 \\
\hline Olenjok (Rus) & Arct. & 219000 & 962 & -14 & 1140 & 0.031 & 35 & 279 & 71 & 29 & 2.42 & & 0.19 \\
\hline Yana (Rus) & Arct. & 220000 & 2369 & -19 & 906 & 0.100 & 95 & 1082 & 162 & 51 & 2.83 & & 0.19 \\
\hline Pechora (Rus) & Arct. & 250000 & 1103 & -6 & 3367 & 0.060 & 193 & 366 & 201 & 187 & 2.43 & & 0.23 \\
\hline Liard (Can) & Arct. & 275000 & 2742 & -2 & 4302 & 0.600 & 2580 & 1506 & 1233 & 837 & 2.85 & 2.80 & 0.25 \\
\hline Peace (Can) & Arct. & 293000 & 3702 & 1 & 2597 & 0.987 & 2563 & 2438 & 659 & 2526 & 3.01 & 2.60 & 0.22 \\
\hline Indigirka (Rus) & Arct. & 305000 & 2682 & -14 & 1711 & 0.260 & 444 & 1533 & 394 & 147 & 2.90 & & 0.20 \\
\hline N. Dvina (Rus) & Arct. & 357000 & 500 & -6 & 3470 & 0.035 & 120 & 50 & 73 & 22 & 2.03 & & 0.23 \\
\hline Kolyma (Rus) & Arct. & 361000 & 1828 & -11 & 2839 & 0.070 & 380 & 939 & 303 & 125 & 2.71 & & 0.22 \\
\hline Khatanga (Rus) & Arct. & 364000 & 2036 & -14 & 2700 & 0.020 & 54 & 1109 & 265 & 143 & 2.76 & & 0.22 \\
\hline Yukon (US) & Pac. & 828800 & 6094 & -12 & 6122 & 0.310 & 1901 & 8872 & 2609 & 1977 & 3.60 & & 0.28 \\
\hline MacKenzie (Can) & Arct. & 1660000 & 3877 & -5 & 10915 & 0.366 & 2219 & 6218 & 3661 & 2683 & 3.20 & 3.00 & 0.37 \\
\hline Amur (Rus) & Pac. & 1850000 & 2133 & -1 & 10552 & 0.160 & 1648 & 2680 & 2524 & 1228 & 2.84 & & 0.36 \\
\hline Yenisei (Rus) & Arct. & 2440000 & 3352 & -13 & 17986 & 0.020 & 412 & 6062 & 1652 & 979 & 3.17 & & 0.50 \\
\hline Lena (Rus) & Arct. & 2486000 & 2529 & -14 & 16650 & 0.034 & 558 & 4011 & 989 & 538 & 3.01 & & 0.47 \\
\hline Ob (Rus) & Arct. & 2929290 & 3657 & -12 & 10299 & 0.050 & 507 & 7570 & 2280 & 938 & 3.24 & & 0.36 \\
\hline \multicolumn{6}{|c|}{$\begin{array}{l}\text { a Area is drainage area at gauging station. } \\
{ }^{\mathrm{b}} H \text { is relief between highest elevation and gauging station. } \\
{ }^{\mathrm{c}} \text { Mean } T \text { is basin temperature averaged over drainage basin. } \\
{ }^{\mathrm{d}} Q \text { is discharge. } \\
{ }^{\mathrm{e}} \mathrm{C} \text { is discharge-weighted sediment concentration. } \\
{ }^{\mathrm{f}} Q s \text { is sediment load. }\end{array}$} & $\begin{array}{l}{ }^{\mathrm{g}} \text { Pred } \\
{ }^{\mathrm{h}} T-P Q \\
{ }^{\mathrm{i}} Q-P C \\
{ }_{\mathrm{j}} \text { Pred } \\
{ }^{\mathrm{k}} C \text { is } \\
{ }^{1} P \sigma-C\end{array}$ & $C$ is t & $\begin{array}{l}\text { red rating } \\
\text { dicted sta }\end{array}$ & andard d & cient. & 010. & $\therefore$ & $\begin{array}{l}\text { 6). } \\
\text { charge. }\end{array}$ \\
\hline
\end{tabular}


quite turbid ( $>1.1 \mathrm{~kg} / \mathrm{m}^{3}$ : Baffin glacial streams). Mean surface temperature averaged across the basin relief ranges from $+4^{\circ} \mathrm{C}$ (Skeena, Stikine) to $-19^{\circ} \mathrm{C}$ (Yana). Mean temperature is derived from a global database of lapse rates and surface temperatures estimated from the National Centers for Environmental Prediction Reanalysis of 17 different pressure level surfaces on a $2.5 \times 2.5$ degree grid, and provided by the National Oceanic and Atmospheric Administration-Climate Diagnostics Center (Boulder). The sediment rating curve is used to define the general behaviour between the sediment load of a river $Q s$, and its water discharge $Q$, i.e. $Q s=a(Q)^{c}$.

\section{Global model to predict sediment load}

Morehead et al. (in press) recently proposed a new stochastic model for the simulation of the sediment discharge of ungauged rivers:

$$
Q s=\psi \overline{Q s}(Q / \bar{Q})^{c}
$$

where $Q s$ is the daily sediment discharge $(\mathrm{kg} / \mathrm{s})$, $\psi$ is a lognormal random variable, $\overline{Q S}$ is the long term average of $Q, Q$ is the daily discharge at the river mouth $\left(\mathrm{m}^{3} / \mathrm{s}\right), \bar{Q}$ is the long term average of $Q$, and $C$ is a normal random variable, otherwise known as the rating coefficient. The following relationships define these terms:

$$
\begin{gathered}
E(\psi)=1 \\
\sigma(\psi)=0.763\left(10^{-0.0000227 \bar{Q}}\right) \\
E(C)=1.4-0.025 \bar{T}+0.00013 H+0.145 \ln (\overline{Q s}) \\
\sigma(C)=0.17+0.0000183 \bar{Q}
\end{gathered}
$$

Equations (2 -5) are developed from North American rivers (Syvitski et al. 2000; Morehead et al. in press). The conditional distribution $\mathrm{F}(\psi)(2$, 3) captures both measurement error and flood dynamics. Large rivers smooth out small perturbations in time-varying sediment and water sources and have relatively small $\sigma(\psi)$. Small rivers are inherently noisy in terms of their discharge signal with larger values of $\sigma(\psi)$. The conditional distribution of the rating coefficient $C$ varies over a time step of one year and is dependent on $\bar{Q}$. Smaller rivers have more characteristic (singular) values of $C$. Rivers with large discharge have greater values of $\sigma(C)$, depending on the importance of their various tributaries to the overall discharge within a given year.

The predicted rating coefficient $C$ for Arctic to

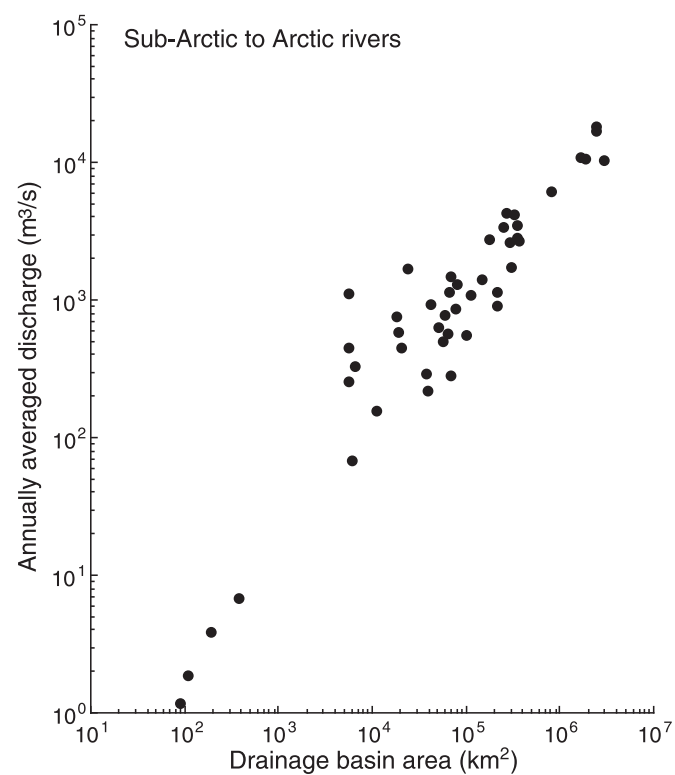

Fig. 2. The annually averaged discharge $(Q)$ scales with the drainage basin area $(A)$ for sub-Arctic and Arctic rivers $\left(Q=0.93 A^{0.82}\right.$ at $\mathrm{R}^{2}=0.892$; Table 1$)$.

sub-Arctic rivers ranges from 1.75 to 3.6 (Table 1), values similar to temperate rivers (Fig. 3; Syvitski et al. 2000). Figure 3 demonstrates that Eq. (4) can reasonably predict the rating coefficient $C$. The prediction of daily sediment load is not sensitive to the rating coefficient, even taking into account the interannual variability of $C$ with Eq. (5) (Fig. 4). The sensitive parameter is $\bar{Q}$.

The long-term average of $Q s$ is defined as:

$$
\overline{Q s}=\alpha H^{3 / 2} \mathrm{~A}^{1 / 2} e^{k \bar{T}}
$$

where $H$ is river basin relief (m), $A$ is river basin area $\left(\mathrm{km}^{2}\right), \bar{T}$ is mean surface temperature of the drainage basin $\left({ }^{\circ} \mathrm{C}\right)$, and $\alpha$ and $k$ are dimensionless constants (respectively $2 \cdot 10^{-5}, 0.1$ ). The original version of Eq. (6) was developed from Mulder \& Syvitski (1996) based on an analysis of the global data set of Milliman \& Syvitski (1992). Syvitski \& Morehead (1999) were the first to incorporate basin temperature as a parameter in Eq. (6), which took its final form in Morehead et al. (in press). While Eq. (6) includes averaged basin temperature across the topography, Syvitski et al. (2000) found that the maximum and minimum temperature within basins closely tracks the average temperature. Figure 1a shows that when basin temperature is not taken into 
account, Eq. (6) over-predicts the magnitude of Arctic to sub-Arctic river load by a factor of 5 (Table 1). When temperature is included in Eq. (6), the predicted sediment discharge from these cold rivers follows the global trend within a factor of 2 (Fig. 1b, Table 1).

Whereas (6) indicates the magnitude of sediment discharge to be a positive function of relief, area (and discharge; Fig. 2) and basin temperature, sediment yield (sediment load per drainage area) decreases with increasing basin size. Storage of sediment on flood plains and delta plains increases with basin area, thus sediment production and transport (yield) decreases with the size of the basin. At the continental scale, very little $(\approx 10 \%)$ eroded sediment actually makes it into the ocean (Meade 1996).

\section{High latitude, low sediment load rivers}

Figure 1 illustrates that drainage basin temperature is a strong determinant on the intensity of sediment production and transport, as captured by the long-term average of sediment load. Other influences could regionally lower sediment loads of Arctic to sub-Arctic rivers, but they are not applicable across the Arctic. For example, 20\% of the Arctic landscape is comprised of old (Precambrian) denudated landscape of granites and gneisses. However, most Table 1 rivers drain more geologically recent and varied rock types. Similarly, our Arctic and sub-Arctic rivers demonstrate little relationship between hydrological run-off (discharge divided by basin area) and the flux of sediment (Table 1).

There are also tens of thousands of lakes distributed around former ice sheet centres, or around Arctic coastal plains (thermokarst lakes). While lakes are important filters of sediment, they are not ubiquitous across the Arctic and do not control the sediment flux for many of the basins in Table 1. Nor should their effectiveness as filters increase with decreasing basin temperatures, as the data in Table 1 indicate. Reservoir construction on $\mathrm{Ob}$ and Yenesei rivers have decreased the sediment loads on these rivers (Bobrovitskaya et al. 1996); however, we use pre-dam values in Table 1.

Another possible influence on Arctic and subArctic river loads is the enormous swaths of landscape without soil-forming vegetation. However these vast regions of exposed rock or ice fields do not define many of the river basins within

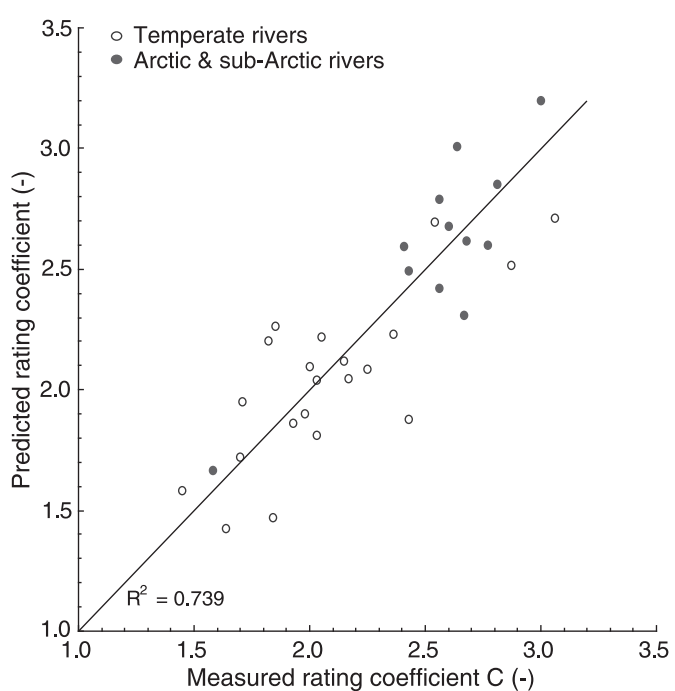

Fig. 3. Predictions (Eq. 4) of rating coefficient $\mathrm{C}$ for unregulated temperate rivers (Syvitski et al. 2000) and Arctic rivers (Table 1).

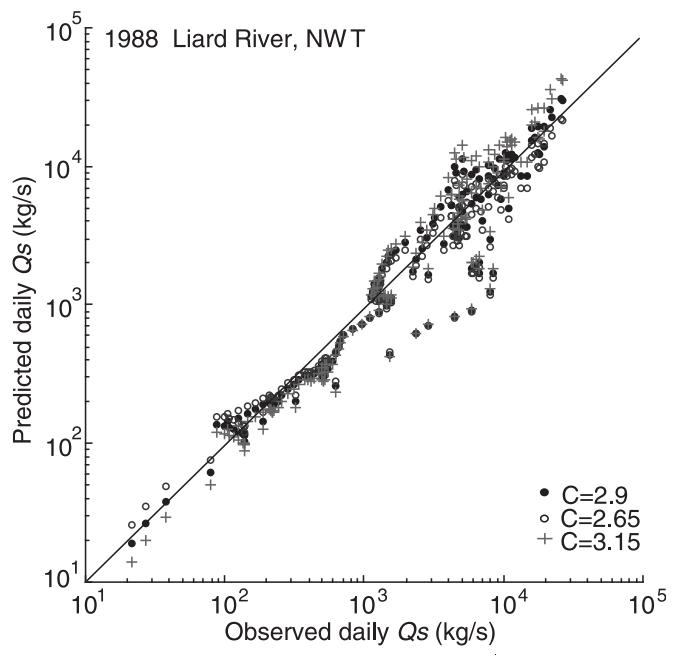

Fig. 4. Predictions (Eq. 1) of daily sediment discharge of the Liard River based on predicted (Eq. 6) mean sediment load $(1233 \mathrm{~kg} / \mathrm{s})$, predicted (Eq. 4) rating coefficient $c(2.9)$, and predicted (Eq. 5) sigma- $c$ (0.25) (Table 1), the long-term discharge $\left(4302 \mathrm{~m}^{3} / \mathrm{s}\right)$ and daily discharge values measured during the calendar year 1988. $\psi$ was set to 1 .

Table 1. Larger Arctic rivers, in contrast, drain vast stretches of boreal forests, but many of the smaller rivers in Table 1 do not. It is reasonable to suggest that these regional influences do account for the scatter not captured by Eq. (6), but they remain secondary in accounting for the low sediment load in Arctic rivers, as captured by 


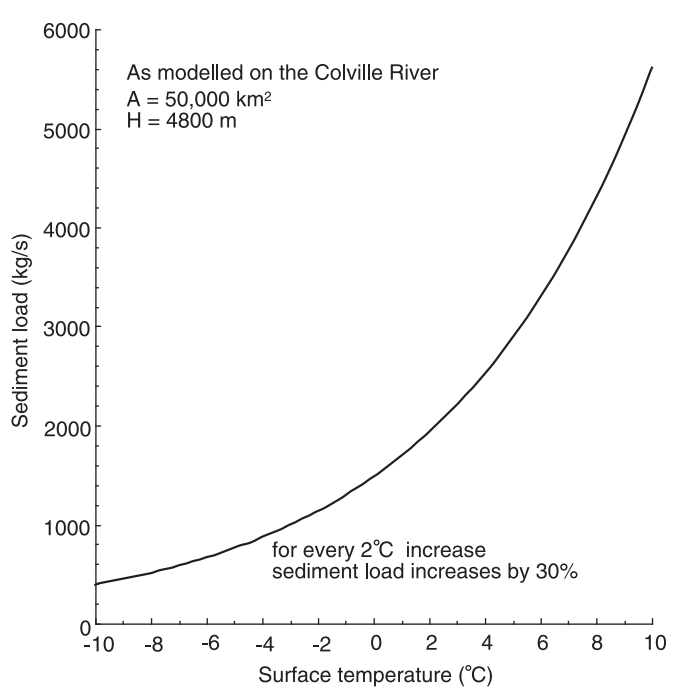

Fig. 5. The sediment load of Arctic rivers is predicted (Eq. 6) to increase by $30 \%$ for every $2{ }^{\circ} \mathrm{C}$ warming of the averaged drainage basin temperature.

basin area, relief and temperature.

Climate has changed over the last 400 years, from the Little Ice Age period of the 17th-19th centuries to today's warming interval of today (Overpeck et al. 1997). Yet sediment discharge as defined by (6) tracks with the modern climate rather than set up conditions from landscape developed during the Pleistocene or early periods of the Holocene (e.g. Sidorchuk et al. 2000). Equation (6) points to sediment production and transport mechanisms that are negatively impacted by low temperatures as the principle causes of the low sediment load of Arctic rivers:

1) the annual rate of freeze-thaw transitions decrease towards the frigid polar region, at least within the alpine weathering environments of drainage basins;

2) soil surface is frozen for much of the year, which limits the erodibility of the terrain;

3 ) as more of the annual precipitation falls as snow, the potential of precipitation to gully terrain and produce sediment decreases;

4) summer precipitation in the Arctic falls largely as low intensity rainfall developed from frontal system, unlike the temperate to tropical regions associated with an increasing occurrence of high-intensity convective rainfall; and

5) snow- or ice-melt flood waves are dampened relative to rainfall-induced flood waves (with rare jokolhlaup events being an exception).

\section{Climate warming and sediment transport by Arctic rivers}

Over the next 100 year period, sea level fluctuations will not greatly impact the drainage areas of rivers, and denudation rates are too slow to impact the relief of these basins. In contrast, the temperature parameter of Eq. (6) provides insight into the consequences of Arctic sediment transport given a climate warming scenario. Equations (1-6) incorporate climate through three terms: time-averaged basin temperature, mean run-off or discharge, and daily discharge. Average drainage basin temperature will obviously show fluctuations between years, but it is across decades that a warming event will affect largescale release of stored water, through melt of permanent snow fields, long term ablation of glaciers or permafrost melt (Syvitski et al. 1998).

Equation (6), as applied to a model river, demonstrates how changes in basin temperature control the production and transport of sediment of high latitude rivers. The model river is based on the basin area and relief of the Colville, Alaska (Table 1). When basin temperatures are varied, Eq. (6) predicts a $22 \%$ increase in sediment load for every $2{ }^{\circ} \mathrm{C}$ warming of the drainage basin (Fig. 5). Since Eq. (6) is a steady state predictor, it is not known how long a transition period will be needed to reach this increase in sediment load. Since Eq. (6) is a function of 20th century basin temperature, change in sediment load due to climate warming will likely occur within decades.

Changes in mean annual run-off may also occur as result of changes in the regional or continental water balance through hydrological feedbacks with changes in atmospheric circulation (Vörösmarty et al. 2001). To incorporate annual discharge directly into (6) we use Fig. 2 and substitute $6.5 \bar{Q}^{0.55}$ for $A^{0.5}$ to arrive at:

$$
\overline{Q s}=1.3 \cdot 10^{-4} H^{3 / 2} \bar{Q}^{0.55} e^{k T}
$$

Equation (7) can predict a river's sediment load as accurately as Eq. (6) (Table 1), though some rivers are better predicted by Eq. (6) and others by (7). Equation (7) indicates that a $20 \%$ increase in discharge, without any intervening basin warming, will result in a $10 \%$ increase in sediment transport. When a basin warming of $2{ }^{\circ} \mathrm{C}$ is combined with a $20 \%$ increase in run-off, the sediment load of Arctic rivers would increase by $32 \%$.

A consequence in the warming of the Arctic will 
be a change in the duration of active discharge. For instance, Magnuson et al. (2000) has found for many Arctic sites that 20th century warming has caused ice break-up in lakes and rivers to occur $10 \mathrm{~d}$ earlier and freeze-up to occur $9 \mathrm{~d}$ later. Changes in the long-term pattern of discharge at the daily level is more a function of changes in regional precipitation intensity, rate changes in snow- and/or ice-melt, and groundwater efflux (Syvitski \& Alcott 1995). Across much of Russia there has been an increase in the number of days with heavy precipitation (Sun et al. 2001).

\section{Conclusions}

The sediment load of pan-Arctic rivers is controlled by surface temperature of the drainage basin, basin area (or volume of water discharged), and basin relief. This is the first study conclusively demonstrating this temperature control on sediment load. The control most likely relates to feedbacks to the hydrological cycle through the extent and impact on frozen soil, and the impact of snow-melt rather than to the direct effect of rainfall in controlling flood wave dynamics.

The Arctic region is undergoing rapid climate change, manifested in impacts on the hydrological cycle and the flux of sediment to the ocean. As the Arctic warms, the rivers will carry increased sediment loads, more like temperate rivers. A stochastic sediment transport model is applied to Arctic rivers to show the magnitude of this increase in sediment load. For every $2{ }^{\circ} \mathrm{C}$ warming there will be a $22 \%$ increase in the flux of sediment carried by rivers and streams. For every $20 \%$ increase in discharge there will be a $10 \%$ increase in sediment load. While river mouths and coastlines near river mouths will see this increase first, decreased ice cover will also give rise to coastal erosion in areas farther away from river mouths. Future studies will be needed to monitor these modelled changes. The provided stochastic model is simple enough to support in the interpretation of marine sedimentary records for their proxy palaeoclimate records in the form of sediment accumulation rates.

Acknowledgements.-This work was supported by National Science Foundation OPP: HARC grant no. 0100120. The model was developed in cooperation with Mark Morehead, Scott Peckham, Eric Hutton, Thierry Mulder and Scott Stewart. Thanks go to the reviewers (R. Stein, V. Rachold and one anonymous reviewer).

\section{References}

Ahnert, F. 1970: Functional relationships between denudation, relief, and uplift in large mid-latitude drainage basins. Am. J. Sci. 268, 243-263.

Alekseev, V. V. \& Lisitsyna, K. N. 1974: Stok vzveshennyk nanosov. (Discharge of suspended sediment.) In: Mirovoi Vodnyi Balans I Vodnye Resursy Zemli. Pp. 510-516. Leningrad: Gidrometeoizdat.

Andrews, J. T. \& Syvitski, J. P. M. 1994: Sediment fluxes along high latitude glaciated continental margins: northeast Canada and eastern Greenland. In W. Hay (ed.): Global sedimentary geofluxes. Pp. 99-115. Washington: National Academy of Sciences Press.

Binda, G. G., Day, T. J. \& Syvitski, J. P. M. 1986: Terrestrial sediment transport into the marine environment of Canada: annotated bibliography and data. Sediment Survey Section Report IWD-HQ-WRB-SS-86-1. Environment Canada.

Bobrovitskaya, N. N., Skakalsky, B. G., Zubkova, K. M., Dobrotvorskaya, G. I., Petrova, I. V., Tsivjyan, M. V., Chistyakova, N. I., Yanuta, V. G., Callender, E. C., Landa, E. R., Meade, R. H., Councell, T. B. \& Bruce, R. A. 1997: Hydrologic and hydrochemical data for the Ob-Irtysh and Yenisey River systems of Central Russia, 1954-1988. U.S.G.S. Open File Report 97-232. U.S. Geological Survey.

Bobrovitskaya, N. N., Zubkova, C. \& Meade, R. H. 1996: Discharges and yields of suspended sediment in the Ob' and Yenisey rivers of Siberia. In D. E. Walling \& B. W. Webb (eds.): Erosion and sediment yield: global and regional perspectives: IAHS Publ. 236, 115-123.

Carmack, E. C. 2000: The Arctic Ocean's freshwater budget: sources, storage and export. In E. L. Lewis et al. (eds.): The freshwater budget of the Arctic Ocean. NATO Sci. Ser. 2. Environmental Security. Vol. 70. Pp. 91-126. Dordrecht: Kluwer Academic Publ.

Douglas, J. 1967: Man, vegetation and the sediment yield of rivers. Nature 215, 925-928.

Dyurgerov, M. B. \& Meier, M. F. 1997: Year to year fluctuations of global mass balance of small glaciers and their contribution to sea level changes. Arct. Alp. Res. 29, 392-402.

Forbes, D. \& Syvitski, J. P. M. 1995: Paraglacial coasts. In C. Woodruffe \& R. W. G. Carter (eds.): Coastal evolution. Pp. 373-424. Cambridge: Cambridge University of Press.

Fournier, F. 1960: Climat et erosion. (Climate and erosion.) Paris: Presses Universitaires de France.

Gordeev, V. V. 2000: River input of water, sediment, major ions, nutrients and trace metals from Russian Territory to the Arctic Ocean. In E. L. Lewis et al. (eds.): The freshwater budget of the Arctic Ocean. NATO Sci. Ser. 2. Environmental Security. Vol. 70. Pp. 297-322. Dordrecht: Kluwer Academic Publ.

Harrison, C. G. 1994: Rates of continental erosion and mountain building. Geol. Rundsch. 83, 431-447.

Hay, W. W., Rosol, M. J., Jory, D. E. \& Sloan II, J. L. 1987: Tectonic control of global patterns and detrital and carbonate sedimentation. In L. J. Doyle and H. H. Roberts (eds.): Carbonate clastic transitions: developments in sedimentology. Pp. 1-34. Amsterdam: Elsevier.

Inman, D. L. \& Jenkins, S. A. 1999: Climate change and the episodicity of sediment flux of small California rivers. $J$. Geol. 107, 251-270.

Jansen, J. M. \& Painter, R. B. 1974: Predicting sediment yield from climate and topography. J. Hydrol. 21, 371-380.

Kovalevsky, V. S. 1998: The impact of climate changes on 
groundwater regimes and resources in Russia. In A. S. Issar \& N. Brown (eds.): Water, environment and society in times of climate change. Pp. 289-293. Dordrecht: Kluwer Academic Publ.

Lammers, R. B., Shiklomanov, A. I., Vörösmarty, C. J., Fekete, B. M. \& Peterson, B. J. 2001: Assessment of contemporary Arctic river runoff based on observational records. J. Geophys. Res. 106(D4), 3321-3334.

Lemeshko N. A. 1992: Changes in surface water balance components with global warming by $1^{\circ} \mathrm{C}$. Water Resour. 4, 64-70.

Lewis, E. L., Jones, P., Lemke, P., Prowse, T. D. \& Wadhams, P. (eds.) 2001: The freshwater budget of the Arctic Ocean. NATO Sci. Ser. 2. Environmental Security. Vol. 70. Dordrecht: Kluwer Academic Publ.

Lisitsyna, K. N. 1974: Suspended sediment discharge of Siberian rivers. State Hydrol. Inst. Proc. 210, 48-72. St. Petersburg.

Lopatin, G. V. 1952: Nanosy rek SSSR. (Sediment in rivers of the USSR.) Zapiski vsesoyuznogo geograficheskogo obschestva 14.

Magnuson, J., Robertson, D., Benson, B., Wynne, R., Livingston, D., Arai, T., Assel, R., Barry, R., Card, V., Kuusisto, E., Granin, N., Prowse, T., Steward, K. \& Vuglinski, V. 2000: Historical trends in lake and river ice cover in the Northern Hemisphere. Science 289, 1743-1746.

Manabe, S., Stouffer, R. J., Spelman, M. J. \& Bryan, K. 1991: Transient responses of a coupled ocean-atmosphere model to gradual changes of atmospheric $\mathrm{CO}_{2}$. Part I: Annual mean response. J. Clim. 4, 785-818.

Maslanik, J. A., Serreze, M. C. \& Agnew, T. 1999: On the record reduction in 1998 western Arctic ice cover. Geophys. Res. Lett. 26, 1905-1908.

Meade, R. H. 1996: River-sediment inputs to major deltas. In J. D. Milliman \& B. U. Haq (eds.): Sea-level rise and coastal subsidence. Pp. 63-85. Dordrecht: Kluwer Academic Publ.

Milliman, J. D. 1980: Transfer of river-borne particulate material to the oceans. In J. Martin et al. (eds.): River inputs to ocean systems. SCOR/UNEP/UNESCO Review and Workshop. Pp. 5-12. Rome: FAO.

Milliman, J. D. \& Meade, R. H. 1983: Worldwide delivery of river sediment to the oceans. J. Geol. 91, 1-21.

Milliman, J. D. \& Syvitski, J. P. M. 1992: Geomorphic/tectonic control of sediment discharge to the ocean: the importance of small mountainous rivers. J. Geol. 100, 525-544.

Morehead, M. D., Syvitski, J. P. M., Hutton, E. W. H. \& Peckham, S. D. in press. Modeling the inter-annual and intraannual variability in the flux of sediment in ungauged river basins. Glob. Planet. Chang.

Mulder, T. \& Syvitski, J. P. M. 1996: Climatic and morphologic relationships of rivers. Implications of sea level fluctuations on river loads. J. Geol. 104, 509-523.

Overpeck, J., Hughen, K., Hardy, R., Bradley, R., Case, R., Douglas, M., Finney, B., Gajewski, K., Jacoby, G., Jennings, A., Lamoureux, S., Lasca, A., MacDonald, G., Moore, J., Retelle, M., Smith, S., Wolfe, A. \& Zielinski, G. 1997: Arctic environmental change in the last four centuries. Science 27, 1251-1256.

Peckham, S. D., Manley, W., Dyurgerov, M. \& Syvitski, J. P. M. 2002: Modeling coastal erosion near Barrow, Alaska. In V. Rachold et al. (eds.): Arctic coastal dynamics. Rep. Polar Mar. Res. 413, 46-47. Bremerhaven: Alfred Wegener Inst.

Petersen, B., Deegan, L., Miller, M., Hershey, A. \& Bowden, B. 1995: The impact of changing climate on Arctic river ecosystems. Witness Arct. 3, 9.

Pinet, P. \& Souriau, M. 1988: Continental erosion and largescale relief. Tectonics 7, 563-582.

Prowse, T. D. \& Flegg, P. O. 2000: Arctic river flow: a review of contributing areas. In: E. L. Lewis et al. (eds.): The freshwater budget of the Arctic Ocean. NATO Sci. Ser. 2. Environmental Security. Vol. 70. Pp. 269-280. Dordrecht: Kluwer Academic Publ.

Serreze, M. C., Walsh, J. E., Chapin III, F. S., Osterkamp, T., Dyurgerov, M., Romanovsky, V., Oechel, W. C., Morrison, J., Zhang, T. \& Barry, R. G. 2000: Observational evidence of recent change in the northern high latitude environment. Clim. Chang. 46, 159-207.

Shiklomanov, A. I., Lammers, R. B. \& Vörösmarty, C. J. 2002: Widespread decline in hydrological monitoring threatens pan-Arctic research. EOS 83(2), 13-17.

Sidorchuk, A. Y., Panin, A. V., Borisova, O. K., Elias, S. A. \& Syvitski, J. P. M. 2000: Channel morphology and river flow in the northern Russian Plain in the Late Glacial and Holocene. Int. J. Earth Sci. 89, 541-549.

Steele, M. \& Boyd, T. 1998: Retreat of the cold halocline layer in the Arctic Ocean. J. Geophys. Res. 103(C5), 10419-10435.

Summerfield, M. A. \& Hulton, N. J. 1994: Natural controls of fluvial denudation rates in major world drainage basins. $J$. Geophys. Res. 99(B7), 13871-13883.

Sun, B., Groisman, P. Y. \& Mokhov, I. I. 2001: Recent changes in cloud type frequency and inferred increases in convection over the United States and the former USSR. $J$. Clim. 14, 1864-1880.

Syvitski, J. P. M. \& Alcott, J. M. 1995: RIVER3: simulation of water and sediment river discharge from climate and drainage basin variables. Comput. Geosci. 21, 89-151.

Syvitski, J. P. M. \& Andrews, J. T. 1994: Climate change: numerical modeling of sedimentation and coastal processes, eastern Canadian Arctic. Arct. Alp. Res. 26, 199-212.

Syvitski, J. P. M. \& Morehead, M. D. 1999: Estimating riversediment discharge to the ocean: application to the Eel Margin, northern California. Mar. Geol. 154, 13-28.

Syvitski, J. P. M., Morehead, M. D., Bahr, D. \& Mulder, T. 2000: Estimating fluvial sediment transport: the rating parameters. Water Resour. Res. 36, 2747-2760.

Syvitski, J. P. M., Morehead, M. D. \& Nicholson, M. 1998: HydroTrend: a climate-driven hydrologic-transport model for predicting discharge and sediment to lakes or oceans. Comput. Geosci. 24, 51-68.

Van Blarcum, S. C., Miller, J. R. \& Russell, G. L. 1995: High latitude river runoff in a doubled $\mathrm{CO}_{2}$ climate. Clim. Chang. 30, 7-26.

Vörösmarty, C. J., Hinzman, L. D., Peterson, B. J., Bromwich, D. H., Hamilton, L. C., Morrison, J., Romanovsky, V. E., Sturm, M. \& Webb, R. S. 2001: The hydrological cycle and its role in Arctic and global environmental change: a rationale and strategy for synthesis study. Fairbanks: Arctic Research Consortium of the U.S

Walling, D. E. 1987: Rainfall, runoff, and erosion of the land: a global view. In K. J. Gregory (ed.): Energetics of the physical environment. London: Wiley. Pp. 89-117.

Wang Y., Ren, M. \& Syvitski, J. P. M. 1998: Sediment transport and terrigenous fluxes. In K. H. Brink \& A. R. Robinson (eds.): The sea. Vol. 10. The global coastal ocean: processes and methods. Pp. 253-292. New York: John Wiley \& Sons.

Wilson, L. 1973: Variations in mean annual sediment yield as a function of mean annual precipitation. Am. J. Sci. 273, $335-349$. 